\title{
Developing a Questionnaire for Prediction of High Salt Intake Based on Salt Usage Behavior: Analysis from Dietary Habits and Urinary Sodium Excretion in Japan
}

\author{
Chika Horikawa1, Nobuko Murayama', Eri Tochikura², Emi Ishida², Miyo Kojima ${ }^{2}$, Sumie Isobe², \\ Kazue Suzuki², Kyoko Fueta3, Miyoko Kira4, Mizue Sasaya5, Misato Koide6, Asako Oyanagi", \\ Rika Yonekura ${ }^{8}$, Yae Iriyama9, Yumi Nakajima10, Chiho Hatano², Junichi Horii ${ }^{2}$
}

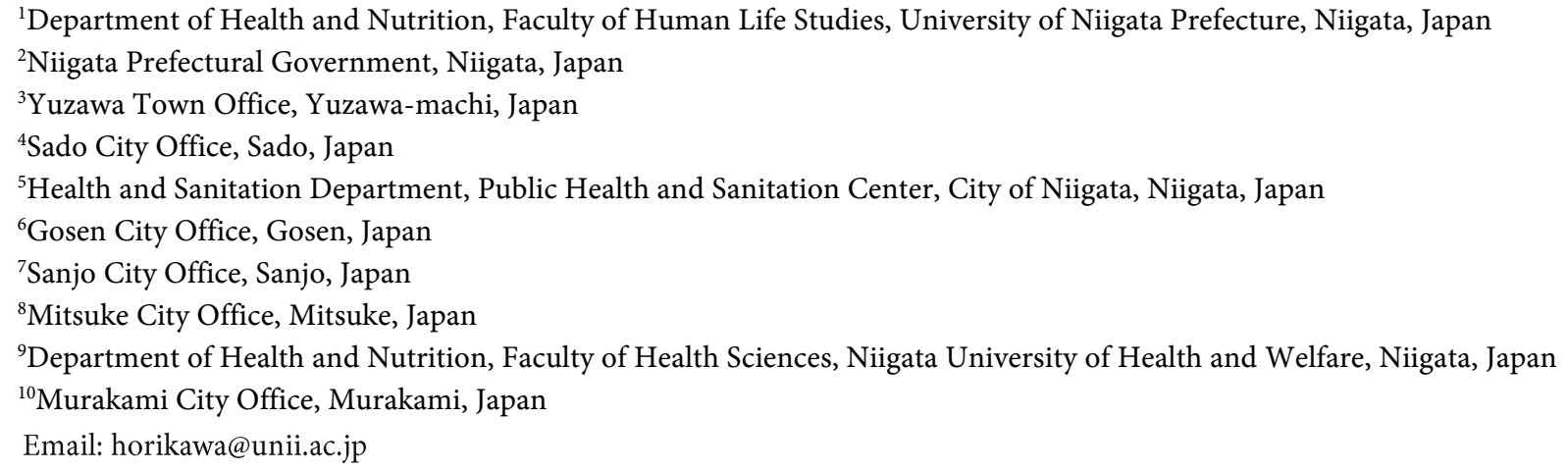

How to cite this paper: Horikawa, C., et al. (2017) Developing a Questionnaire for Prediction of High Salt Intake Based on Salt Usage Behavior: Analysis from Dietary Habits and Urinary Sodium Excretion in Japan. Food and Nutrition Sciences, 8, 118.

http://dx.doi.org/10.4236/fns.2017.81001

Received: August 15, 2016

Accepted: December 6, 2016

Published: December 9, 2016

Copyright $\odot 2017$ by authors and Scientific Research Publishing Inc. This work is licensed under the Creative Commons Attribution International License (CC BY 4.0).

http://creativecommons.org/licenses/by/4.0/

(c) (i) Open Access

\section{Abstract}

Salt reduction policies have been implemented throughout the world as well as in Japan. However, most of the current questionnaires for estimating salt intake are apt to be based on empirical evidence. This study was aimed to develop and validate a questionnaire for predicting high salt intake based on salt usage using dietary behaviors that affect salt intake in cooperation with Niigata prefecture, Japan. The study was comprised of 760 participants aged 21 - 79 years (Men\%: 49\%) living in Niigata. Participants completed a questionnaire about dietary behaviors potentially relevant to salt intake. Second morning voiding urine for estimating dietary salt intake per day was collected on the same day. The relationship of estimated dietary salt intake to answers on the questionnaire was examined using analysis of covariance for age, gender, body mass index, and whether taking medication or not. Ten items on the questionnaire revealed an association with dietary salt intake per day: making oneself gorge on a meal, having $\geq 2$ different staples per meal, having a 1-dish meal, number of simmered dishes per day, variety of pickled vegetables per day, having salt-cured fish eggs per day, quantity of soup consumed when eating noodles, preference for strong-tasting meals, frequency of eating out, and frequency of alcohol consumption. 
The current study identified 10 dietary behaviors that enabled the development of a salt intake questionnaire for identifying specific dietary behaviors for assessing regions and/or individuals when attempting to encourage salt reduction.

\section{Keywords}

Salt Intake, Dietary Behavior, Second Morning Voiding Urine, Urinary Sodium, Japanese

\section{Introduction}

There is conclusive evidence on the adverse effects of excessive dietary sodium consumption on blood pressure, and multiple observational studies showed clear correlations of sodium consumption with cardiovascular disease as well as a range of other conditions including gastric cancer, osteoporosis, cataracts, kidney stones, and diabetes [1]. Reduction in dietary salt intake is encouraged throughout the world. The World Health Organization aimed to achieve a target salt intake of less than $5 \mathrm{~g} /$ day and a mean reduction in salt intake of $30 \%$ by the worldwide population by 2025 [2]. Many individual countries are engaged in salt reduction policies [3]. In Japan, which faces the issue of high dietary salt intake compared with Western countries, the target for dietary salt intake was reduced from 9.0 to $8.0 \mathrm{~g} /$ day in men and from 7.5 to $7.0 \mathrm{~g} / \mathrm{day}$ in women since the Dietary Reference Intakes for Japanese (2015) was issued [4].

Providing support for strengthening the dietary goal for salt intake is required for national salt reduction policies centered on enlightenment about traditional salty foods and cooking methods for salt reduction. The Japanese mean dietary salt intake was reduced $3.0 \mathrm{~g} /$ day in 24 years; that is from $13.7 \mathrm{~g} /$ day in 1981 to $10.7 \mathrm{~g} /$ day in 2004 [5] [6]. On the other hand, the reduction rate of salt intake in the recent decade has been gradual: to $10.2 \mathrm{~g} /$ day in 2013 [7]. To reduce salt intake by Japanese to less than $10.0 \mathrm{~g} / \mathrm{day}$ is unrealistic if there is not a sufficient salt restriction policy to enable regions and/or individuals to put knowledge about salty foods and cooking methods into practical action to reduce salt intake. Working relationships with public health nutritionists and other professionals in prefectural and municipal governments, and university researchers have been established in Niigata Prefecture since 2013, making it a particularly advanced prefecture engaged in salt reduction in Japan. Surveys and analyses are ongoing to improve the efficacy of salt restriction policies, appropriate measures are planned through the Plan-Do-Check-Act cycle, and an effective program for salt restriction policies is being developed [8].

As a first step, methods have been discussed on how to carry out appropriate assessments and education for regions and/or individuals using information on dietary behavior affecting high salt intake based on scientific evidence of the current situation in the population. However, there is not a scientifically reliable questionnaire to estimate salt intake based on dietary behavior rather than rules of thumb based on experience although there are many salt intake questionnaires in the world, including Japan, to assess salt intake and provide education for salt reduction [9] [10] [11]. Therefore, with 
the cooperation of Niigata prefecture, Japan, the aim of this study was to develop and validate a salt intake questionnaire that can allow the prediction of high salt intake based on salt usage in relation to dietary behavior.

\section{Methods}

The study was comprised of 760 participants, aged 21 - 79 years, living in Niigata Prefecture, Japan, and lead by a working group in Niigata prefecture that provided data analysis and made policy recommendations to create a nutrition policy and evaluation system. The protocol for the study, which is in accordance with the Declaration of Helsinki and the Ethical Guidelines for Clinical/Epidemiological Studies of the Japanese Ministry of Health Labor and Welfare, received ethical approval from the institutional review boards of all of the participating institutes. Written informed consent was obtained from all participants enrolled. The survey for participants was carried out in 2014, and within one day, participants completed a questionnaire regarding dietary habits potentially relevant to salt intake and underwent collection of second morning voiding urine (SMU) and other assessments.

All participants completed the questionnaire on dietary behavior potentially relevant to salt intake. Construction of the questionnaire was based on the frequency of eating salty and other foods, and behaviors and attitudes related to salt intake cited from an empirical perspective gained from interviews with registered dietitians associated with public administrations or medical services. Content of the resultant questionnaire and possible responses are shown in Table 2.

SMU for estimating dietary salt intake per day was collected from participants. Estimated sodium excretion from SMU was validated with that of 24 -h urinary $(24 \mathrm{HU})$ excretion and the obtained formulas for 24 -h urinary sodium excretion $(24 \mathrm{HUNaV})$ were reported as follows [12]: 1) $\mathrm{PRCr}(\mathrm{mg} /$ day) of men $=15.12 \times$ weight $(\mathrm{kg})+7.39 \times$ height $(\mathrm{cm})-12.63 \times$ age (year) -79.90 , and $\mathrm{PRCr}(\mathrm{mg} /$ day) of women $=8.58 \times$ weight $(\mathrm{kg})+5.09 \times$ height $(\mathrm{cm})-4.72 \times$ age (year) -74.95 ; and 2$)$ estimated $24 \mathrm{HUNaV}$ $(\mathrm{mEq} /$ day $)=16.3 \times(\mathrm{SMUNa} / \mathrm{SMUCr} \times \mathrm{PRCr}) 0.5$; where $\mathrm{PRCr}=$ predicted value of $24 \mathrm{HUCr}, \mathrm{SMUNa}=\mathrm{Na}$ concentration in the SMU and SMUCr $=$ creatinine concentration in the SMU. There were reported high significant correlations between the values estimated by $24 \mathrm{HUNaV}$ and $\mathrm{Na}$ measured by $24 \mathrm{~h}$ urine specimens for a 3-5 day period $(\mathrm{r}=0.728, p<0.001)$. Estimated $24 \mathrm{HUNaV}$ was calculated to reflect dietary salt intake by the following formula: dietary salt intake $(\mathrm{g} /$ day $)=24 \mathrm{HUNaV}(\mathrm{mg} /$ day $) / 1000 \times 2.54$. A physical examination that included height, weight, and blood pressure measurements was conducted. A questionnaire was also used to determine smoking status and medications used for hypertension, hyperglycemia, or hyperlipidemia.

Patient characteristics were described as mean $\pm \mathrm{SD}$ or percentage. Differences in the major characteristics according to age and gender were examined by t-tests or Chisquare tests. The relationships of salt intake to answers to the questionnaire regarding dietary behavior potentially relevant to salt intake were then examined using analysis of covariance for age, gender, body mass index (BMI), and whether taking medication (antihypertensive agents, insulin or oral hypoglycemic agents, or lipid-lowering agents). All $p$-values are two-sided, and the significance level is 0.05 . All statistical analyses were carried out using SPSS Statistics 23 (IBM, New York, NY, USA). 


\section{Results}

\subsection{Characteristics of Participants}

Table 1 shows the characteristics of the 760 participants according to age and gender. Mean daily salt intake was 14.0 and $11.7 \mathrm{~g}$ in men and women, respectively, aged from 20 to 59 years $(p<0.001)$, and 11.3 and $10.9 \mathrm{~g}$ in men and women, respectively, aged 60

Table 1. Characteristics of participants who completed a questionnaire on dietary habits potentially relevant to salt intake and who underwent collection of spot urine.

\begin{tabular}{|c|c|c|c|c|c|c|c|}
\hline & & & \multicolumn{4}{|c|}{$20-59$ years $(\mathrm{N}=492)$} & \multirow{3}{*}{$p$-value } \\
\hline & & & \multicolumn{2}{|c|}{ Male $(\mathrm{N}=269)$} & \multicolumn{2}{|c|}{ Female (N = 223) } & \\
\hline & & & $\begin{array}{l}\text { No. } \\
\text { Participants }\end{array}$ & $\%$ & $\begin{array}{l}\text { No. } \\
\text { Participants }\end{array}$ & $\%$ & \\
\hline \multirow[t]{4}{*}{ Age-groups a } & $20-$ & 9 years & 57 & $21.2 \%$ & 48 & $21.5 \%$ & \multirow{4}{*}{0.73} \\
\hline & 30 & 9 years & 19 & $7.1 \%$ & 12 & $5.4 \%$ & \\
\hline & 40 & 9 years & 122 & $45.4 \%$ & 96 & $43.0 \%$ & \\
\hline & 50 & 9 years & 71 & $26.4 \%$ & 67 & $30.0 \%$ & \\
\hline Salt intake (g/day) b & & & 14.0 & \pm 4.4 & 11.7 & \pm 3.4 & $<0.001$ \\
\hline Height $(\mathrm{cm}) \mathrm{b}$ & & & 171.4 & \pm 6.0 & 159.2 & \pm 5.7 & $<0.001$ \\
\hline Weight $(\mathrm{kg}) \mathrm{b}$ & & & 71.1 & \pm 12.8 & 56.1 & \pm 10.2 & $<0.001$ \\
\hline Body mass index $\left(\mathrm{kg} / \mathrm{cm}^{2}\right) \mathrm{b}$ & & & 24.2 & \pm 4.2 & 22.1 & \pm 3.9 & $<0.001$ \\
\hline Systolic blood pressure $(\mathrm{mmHg}) \mathrm{b}$ & & & 123.4 & \pm 13.7 & 116.3 & \pm 13.9 & $<0.001$ \\
\hline Diastolic blood pressure $(\mathrm{mmHg}) \mathrm{b}$ & & & 78.1 & \pm 11.0 & 73.3 & \pm 10.5 & $<0.001$ \\
\hline \multirow{2}{*}{\multicolumn{2}{|c|}{ Treated by antihypertensive agents (\%) a }} & Yes & 38 & $14.1 \%$ & 13 & $5.8 \%$ & \multirow{2}{*}{0.003} \\
\hline & & No & 231 & $85.9 \%$ & 210 & $94.2 \%$ & \\
\hline \multirow{2}{*}{$\begin{array}{l}\text { Treated by insulin or oral hypoglycemic } \\
\text { agents (\%) a }\end{array}$} & & Yes & 5 & $1.9 \%$ & 2 & $0.9 \%$ & \multirow{2}{*}{0.37} \\
\hline & & No & 264 & $98.1 \%$ & 221 & $99.1 \%$ & \\
\hline \multirow{2}{*}{\multicolumn{2}{|c|}{ Treated by lipid-lowering agents (\%) a }} & Yes & 23 & $8.6 \%$ & 16 & $7.2 \%$ & \multirow{2}{*}{0.57} \\
\hline & & No & 246 & $91.4 \%$ & 207 & $92.8 \%$ & \\
\hline \multirow[t]{5}{*}{ Current smoker (\%) a } & & Yes & 107 & $39.8 \%$ & 25 & $11.2 \%$ & \multirow{2}{*}{$<0.001$} \\
\hline & & No & 162 & $60.2 \%$ & 198 & $88.8 \%$ & \\
\hline & & & \multicolumn{4}{|c|}{$60-79$ years $(\mathrm{N}=268)$} & \\
\hline & & & \multicolumn{2}{|c|}{ Male $(\mathrm{N}=105)$} & \multicolumn{2}{|c|}{ Male $(\mathrm{N}=105)$} & \\
\hline & & & $\begin{array}{l}\text { No. } \\
\text { Participants }\end{array}$ & $\%$ & $\begin{array}{c}\text { No. } \\
\text { Participants }\end{array}$ & $\%$ & $p$-value \\
\hline \multirow[t]{2}{*}{ Age-groups a } & 60 & 9 years & 79 & $75.2 \%$ & 126 & $77.3 \%$ & \multirow[t]{2}{*}{0.70} \\
\hline & 70 & 9 years & 26 & $24.8 \%$ & 37 & $22.7 \%$ & \\
\hline Salt intake (g/day) b & & & 11.3 & \pm 3.8 & 10.9 & \pm 3.0 & 0.37 \\
\hline Height $(\mathrm{cm}) \mathrm{b}$ & & & 164.6 & \pm 6.2 & 152.1 & \pm 5.6 & $<0.001$ \\
\hline Weight $(\mathrm{kg}) \mathrm{b}$ & & & 64.5 & \pm 10.6 & 53.9 & \pm 10.0 & $<0.001$ \\
\hline Body mass index $\left(\mathrm{kg} / \mathrm{cm}^{2}\right) \mathrm{b}$ & & & 23.8 & \pm 3.3 & 23.3 & \pm 4.2 & 0.29 \\
\hline Systolic blood pressure $(\mathrm{mmHg}) \mathrm{b}$ & & & 132.7 & \pm 18.0 & 126.0 & \pm 16.0 & 0.002 \\
\hline Diastolic blood pressure $(\mathrm{mmHg}) \mathrm{b}$ & & & 80.3 & \pm 11.3 & 74.4 & \pm 10.1 & $<0.001$ \\
\hline \multirow{2}{*}{\multicolumn{2}{|c|}{ Treated by antihypertensive agents (\%) a }} & Yes & 15 & $14.3 \%$ & 32 & $19.6 \%$ & \multirow{2}{*}{0.26} \\
\hline & & No & 90 & $85.7 \%$ & 131 & $80.4 \%$ & \\
\hline \multirow{2}{*}{$\begin{array}{l}\text { Treated by insulin or oral } \\
\text { hypoglycemic agents (\%) a }\end{array}$} & & Yes & 3 & $2.9 \%$ & 9 & $5.5 \%$ & \multirow{2}{*}{0.30} \\
\hline & & No & 102 & $97.1 \%$ & 154 & $94.5 \%$ & \\
\hline \multirow{2}{*}{\multicolumn{2}{|c|}{ Treated by lipid-lowering agents (\%) a }} & Yes & 6 & $5.7 \%$ & 24 & $14.7 \%$ & \multirow{2}{*}{0.022} \\
\hline & & No & 99 & $94.3 \%$ & 139 & $85.3 \%$ & \\
\hline Current smoker (\%) a & & Yes & 20 & $19.0 \%$ & 4 & $2.5 \%$ & $<0.001$ \\
\hline current smoker (\%) a & & No & 85 & $81.0 \%$ & 159 & $97.5 \%$ & \\
\hline
\end{tabular}

a. One-way ANOVA was used. b. Chi-square test was used. 
to 79 years $(p=0.37)$. BMI, systolic blood pressure, and diastolic blood pressure in men were significantly higher than in women regardless of age. The prevalence of men treated by antihypertensive agents was significantly higher than women aged 20 to 59 years, but the prevalence was not significantly different between men and women aged 60 to 79 years ( $p=0.003$ and $p=0.26$, respectively). Among participants aged 60 to 79 years, the percentage of women treated by lipid-lowering agents was higher than that of men $(p=0.022)$. There were no significant differences between men and women in the prevalence of participants using insulin or oral hypoglycemic agents at any age.

\subsection{Dietary Salt Intake and Responses to the Questionnaire}

Table 2 shows dietary salt intake according to the responses to the questionnaire on dietary behaviors potentially relevant to salt intake. Ten items on the questionnaire showed an association with dietary salt intake per day: making oneself gorge on a meal (everyday vs. $\leq 2$ times/week: 12.6 and $10.7 \mathrm{~g}, p=0.038$ ), having $\geq 2$ different staple foods per meal ( $\geq 3$ vs. $\leq 2$ times/week: 12.8 and $12.1 \mathrm{~g}, p=0.034$ ), having a 1-dish meal ( $\geq 3$ vs. $\leq 2$ times/week: 12.5 and $12.0 \mathrm{~g}, p=0.046$ ), number of simmered dishes per day ( $\geq 4$ servings vs. $\leq 1$ serving/ 2 days: 13.9 and $11.3 \mathrm{~g}, p=0.001$ ), types of pickled vegetables per day ( $\geq 2$ types vs. $\leq 1$ type/ 2 days: 12.9 and $11.8 \mathrm{~g}, p=0.027$ ), having salt-cured fish eggs per day ( $\geq 1$ time vs. $\leq 1$ serving/2 days: 12.8 and $12.1 \mathrm{~g}, p=0.024$ ), quantity of soup consumed when eating noodles ( $\geq 1 / 3$ vs. very little: 12.4 and $11.6 \mathrm{~g}, p=0.044$ ), preference for strong-tasting meals (yes vs. no: 12.7 and $12.0 \mathrm{~g}, p=0.013$ ), frequency of eating out ( $\geq 2$ vs. $\leq 1$ time/week: 12.7 and $12.1 \mathrm{~g}, p=0.05$ ), and frequency of alcohol consumption (daily, occasionally, and very infrequently: 13.1, 12.1, and $11.9 \mathrm{~g}, p=$ 0.018 (daily vs. occasionally) and 0.001 (daily vs. very infrequently), respectively).

\subsection{Dietary Salt Intake and Responses to the Questionnaire by Age}

Table 3 shows the dietary salt intake and the responses to the questionnaire according to whether participants were 20 to 59 years old or were 60 to 79 years old. The relationship with dietary salt intake was reduced in 2 of 10 items in the questionnaire that were described above regardless of the age group: making oneself gorge on a meal and frequency of alcohol consumption. However, the significant associations remained in participants 20 to 59 years old in 5 of the 10 items: having $\geq 2$ different staple foods per meal ( $\geq 3$ vs. $\leq 2$ times/week: 13.7 and $12.6 \mathrm{~g}, p=0.004$ ), having a 1 -dish meal ( $\geq 3$ vs. $\leq 2$ times/week: 13.3 and $12.3 \mathrm{~g}, p=0.004$ ), having salt-cured fish eggs per day ( $\geq 1$ times vs. $\leq 1$ serving/2 days: 13.6 and $12.7 \mathrm{~g}, p=0.022)$, quantity of soup consumed when eating noodles ( $\geq 1 / 3$ vs. very little: 13.1 and $11.3 \mathrm{~g}, p=0.011$ ), and frequency of eating out $(\geq 2$ vs. $\leq 1$ time/week: 13.6 and $12.6 \mathrm{~g}, p=0.005)$. There were significant associations in participants from 60 to 79 years of age in 3 of the 10 items: number of simmered dishes per day ( $\geq 4$ servings vs. $\leq 1$ serving/2 days: 12.2 and $9.2 \mathrm{~g}, p=0.002$ ), types of pickled vegetables per day ( $\geq 2$ types, 1 type, and $\leq 1$ type/2 days: $11.9,10.6$, and $10.0 \mathrm{~g}, p=0.011$ ( $\geq 2$ types vs. 1 type) and 0.006 ( $\geq 2$ types vs. $\leq 1$ type/2 days), respectively), and preference for strong-tasting meals (yes vs. no: 11.7 and $10.7 \mathrm{~g}, p=0.020$ ). Additionally, participants in the older age group who used delicatessen food $\leq 1$ times a week had a significantly higher dietary salt intake than those using delicatessen food $\geq 2$ times a week (11.3 $\mathrm{g}$ and $10.0 \mathrm{~g}$, respectively, $p=0.016$ ). 
Table 2. Dietary salt intake and responses to the questionnaire on dietary habits potentially relevant to salt intake.

\begin{tabular}{|c|c|c|c|c|c|}
\hline Questionnaire items & Answer & $\begin{array}{c}\text { No. } \\
\text { Participants }\end{array}$ & Mean & $95 \%$ CI & $p$-value \\
\hline \multirow[t]{4}{*}{ Making oneself gorge on a meal } & everyday & 226 & 12.6 & (12.1 to 13.1$)$ & - \\
\hline & 5 - 6 times/week & 354 & 12.3 & (11.9 to 12.7$)$ & 0.99 \\
\hline & 3 - 4 times/week & 143 & 12.2 & (11.5 to 12.8$)$ & 0.99 \\
\hline & $\leq 2$ times/week & 37 & 10.7 & (9.5 to 11.9 ) & 0.038 \\
\hline Having $\geq 2$ different staple foods & $\geq 3$ times/week & 198 & 12.8 & (12.2 to 13.3$)$ & - \\
\hline per meal & $\leq 2$ times/week & 562 & 12.1 & (11.8 to 12.4$)$ & 0.034 \\
\hline \multirow[t]{2}{*}{ Having a 1-dish meal } & $\geq 3$ times/week & 419 & 12.5 & (12.2 to 12.9$)$ & - \\
\hline & $\leq 2$ times/week & 341 & 12.0 & (11.6 to 12.4$)$ & 0.046 \\
\hline \multirow{4}{*}{ Number of simmered dishes per day } & $\geq 4$ servings & 45 & 13.9 & (12.8 to 15.0$)$ & - \\
\hline & $2-3$ servings & 270 & 12.3 & (11.9 to 12.8$)$ & 0.06 \\
\hline & 1 serving & 325 & 12.4 & (12.0 to 12.8$)$ & 0.08 \\
\hline & $\leq 1$ serving/ 2 days & 120 & 11.3 & (10.6 to 12.0$)$ & 0.001 \\
\hline \multirow[t]{5}{*}{ Number of soups per day } & $\geq 3$ servings & 66 & 12.5 & (11.6 to 13.5$)$ & - \\
\hline & 2 servings & 247 & 12.4 & (11.9 to 12.9$)$ & 0.99 \\
\hline & 1 serving & 360 & 12.3 & (11.9 to 12.7 ) & 0.99 \\
\hline & $\leq 1$ serving/2 days & 87 & 11.7 & (10.9 to 12.5$)$ & 0.99 \\
\hline & $\geq 2$ types & 169 & 12.9 & (12.3 to 13.5$)$ & - \\
\hline \multirow[t]{3}{*}{ Types of pickled vegetables per day } & 1 type & 340 & 12.3 & (11.9 to 12.7$)$ & 0.31 \\
\hline & $\leq 1 / 2$ days & 251 & 11.8 & (11.4 to 12.3$)$ & 0.027 \\
\hline & $\geq 1$ time & 202 & 12.8 & (12.3 to 13.3$)$ & - \\
\hline Having salt-cured fish eggs per day & $\leq 1$ serving/ 2 days & 558 & 12.1 & (11.8 to 12.4 ) & 0.024 \\
\hline \multirow[t]{3}{*}{ Having salty snacks per day } & $\geq 2$ times & 41 & 12.5 & (11.3 to 13.6$)$ & - \\
\hline & 1 time & 337 & 12.3 & (11.8 to 12.7$)$ & 0.99 \\
\hline & $\leq 1 / 2$ days & 382 & 12.3 & (11.9 to 12.7 ) & 0.99 \\
\hline \multirow{3}{*}{$\begin{array}{c}\text { Quantity of soup consumed when eating } \\
\text { noodles }\end{array}$} & $\geq 1 / 3$ & 653 & 12.4 & (12.1 to 12.7$)$ & - \\
\hline & very little & 107 & 11.6 & $(10.8$ to 12.3$)$ & 0.044 \\
\hline & Yes & 459 & 12.5 & (12.1 to 12.8$)$ & - \\
\hline \multirow{2}{*}{ Addition of seasoning to cooked dishes } & No & 301 & 12.0 & (11.5 to 12.4$)$ & 0.10 \\
\hline & Yes & 300 & 12.7 & (12.3 to 13.1$)$ & - \\
\hline \multirow{2}{*}{ Preference for strong-tasting meals } & No & 460 & 12.0 & (11.6 to 12.3$)$ & 0.013 \\
\hline & $\geq 2$ times/week & 251 & 12.3 & (11.8 to 12.7$)$ & - \\
\hline Frequency of using delicatessen food & $\leq 1$ time/week & 509 & 12.3 & (11.9 to 12.6$)$ & 0.97 \\
\hline \multirow[t]{2}{*}{ Frequency of eating out } & $\geq 2$ times/week & 225 & 12.7 & (12.2 to 13.2 ) & - \\
\hline & $\leq 1$ time/week & 535 & 12.1 & (11.8 to 12.4$)$ & 0.05 \\
\hline
\end{tabular}




\section{Continued}

\begin{tabular}{|c|c|c|c|c|c|}
\hline \multirow{2}{*}{ Whether trying to reduce salt intake } & trying actively & 90 & 11.6 & (10.8 to 12.4$)$ & - \\
\hline & trying a little & 308 & 12.4 & (12.0 to 12.8$)$ & 0.50 \\
\hline \multirow{6}{*}{$\begin{array}{l}\text { Use of dashi flavor, broth, or stock } \\
\text { and the natural taste of food }\end{array}$} & not trying much & 243 & 12.3 & (11.8 to 12.8$)$ & 0.99 \\
\hline & not trying at all & 119 & 12.4 & (11.7 to 13.1$)$ & 0.99 \\
\hline & trying actively & 132 & 12.1 & (11.5 to 12.8$)$ & - \\
\hline & trying a little & 271 & 12.1 & (11.7 to 12.6$)$ & 0.99 \\
\hline & not trying much & 233 & 12.7 & (12.2 to 13.2$)$ & 0.93 \\
\hline & not trying at all & 124 & 11.9 & (11.2 to 12.6$)$ & 0.99 \\
\hline \multirow{3}{*}{$\begin{array}{l}\text { Whether trying to have a } \\
\text { meal consisting of a staple food, } \\
\text { main dish, and side dishes }\end{array}$} & trying actively & 142 & 12.2 & (11.5 to 12.8$)$ & - \\
\hline & trying a little & 218 & 12.4 & (11.9 to 12.9$)$ & 0.99 \\
\hline & not trying much & 303 & 12.3 & (11.9 to 12.8$)$ & 0.99 \\
\hline \multirow{4}{*}{ Frequency of alcohol consumption } & not trying at all & 97 & 12.1 & (11.3 to 12.8$)$ & 0.99 \\
\hline & daily & 198 & 13.1 & (12.6 to 13.7 ) & - \\
\hline & occasionally & 216 & 12.1 & (11.6 to 12.6$)$ & 0.018 \\
\hline & $\leq 1$ serving $/ 2$ days & 346 & 11.9 & (11.5 to 12.3$)$ & 0.001 \\
\hline
\end{tabular}

Analyses were conducted by analysis of covariance for age, gender, BMI, and whether taking medicine or not (antihypertensive agents, insulin or oral hypoglycemic agents, or lipid-lowering agents).

Table 3. Dietary salt intake and responses to the questionnaire on dietary habits potentially relevant to salt intake according to age.

\begin{tabular}{|c|c|c|c|c|c|}
\hline \multirow[b]{2}{*}{ Questionnaire items } & \multirow[b]{2}{*}{ Answer } & \multicolumn{3}{|c|}{$20-59$ years $(\mathrm{N}=492)$} & \multirow[b]{2}{*}{$p$-value } \\
\hline & & $\begin{array}{c}\text { No. } \\
\text { Participants }\end{array}$ & Mean & $95 \% \mathrm{CI}$ & \\
\hline \multirow[t]{4}{*}{ Making oneself gorge on a meal } & everyday & 171 & 13.2 & (12.6 to 13.8$)$ & - \\
\hline & 5 - 6 times/week & 240 & 12.8 & (12.3 to 13.3$)$ & 0.99 \\
\hline & 3 - 4 times/week & 69 & 13.3 & (12.4 to 14.3$)$ & 0.99 \\
\hline & $\leq 2$ times/week & 12 & 11.1 & $(8.8$ to 13.3$)$ & 0.47 \\
\hline Having $\geq 2$ different staple foods & $\geq 3$ times/week & 147 & 13.7 & (13.1 to 14.4$)$ & - \\
\hline per meal & $\leq 2$ times/week & 345 & 12.6 & (12.2 to 13$)$ & 0.004 \\
\hline \multirow[t]{2}{*}{ Having a 1-dish meal } & $\geq 3$ times/week & 315 & 13.3 & (12.9 to 13.8$)$ & - \\
\hline & $\leq 2$ times/week & 177 & 12.3 & (11.7 to 12.8$)$ & 0.004 \\
\hline \multirow{4}{*}{$\begin{array}{l}\text { Number of simmered } \\
\text { dishes per day }\end{array}$} & $\geq 4$ servings & 18 & 14.9 & (13.0 to 16.7$)$ & - \\
\hline & 2 - 3 servings & 142 & 12.9 & (12.3 to 13.6$)$ & 0.34 \\
\hline & 1 serving & 248 & 13.0 & (12.5 to 13.5$)$ & 0.35 \\
\hline & $\leq 1$ serving/2 days & 84 & 12.4 & (11.6 to 13.3 ) & 0.11 \\
\hline \multirow[t]{2}{*}{ Number of soups per day } & $\geq 3$ servings & 36 & 13.8 & $(12.5$ to 15.1$)$ & - \\
\hline & 2 servings & 163 & 13.1 & (12.5 to 13.7$)$ & 0.99 \\
\hline
\end{tabular}




\begin{tabular}{|c|c|c|c|c|c|}
\hline & 1 serving & 236 & 12.9 & (12.4 to 13.4$)$ & 0.99 \\
\hline & $\leq 1$ serving/ 2 days & 57 & 12.1 & (11.0 to 13.1$)$ & 0.23 \\
\hline & $\geq 2$ types & 64 & 13.3 & (12.3 to 14.2$)$ & - \\
\hline \multirow[t]{2}{*}{ Types of pickled vegetables per day } & 1 type & 220 & 13.1 & (12.6 to 13.6$)$ & 0.99 \\
\hline & $\leq 1 / 2$ days & 208 & 12.7 & (12.1 to 13.2$)$ & 0.90 \\
\hline \multirow{2}{*}{$\begin{array}{l}\text { Having salt-cured } \\
\text { fish eggs per day }\end{array}$} & $\geq 1$ time & 131 & 13.6 & (13.0 to 14.3 ) & - \\
\hline & $\leq 1$ serving/ 2 days & 361 & 12.7 & (12.3 to 13.1$)$ & 0.022 \\
\hline \multirow[t]{3}{*}{ Having salty snacks per day } & $\geq 2$ times & 11 & 13.7 & (11.4 to 16.1$)$ & - \\
\hline & 1 time & 232 & 12.8 & (12.3 to 13.3$)$ & 0.99 \\
\hline & $\leq 1 / 2$ days & 249 & 13.1 & (12.6 to 13.6$)$ & 0.99 \\
\hline \multirow{2}{*}{$\begin{array}{l}\text { Quantity of soup consumed } \\
\text { when eating noodles }\end{array}$} & $\geq 1 / 3$ & 455 & 13.1 & (12.7 to 13.4$)$ & - \\
\hline & Very little & 37 & 11.3 & (10.0 to 12.6$)$ & 0.011 \\
\hline \multirow{2}{*}{$\begin{array}{l}\text { Addition of seasoning } \\
\text { to cooked dishes }\end{array}$} & Yes & 355 & 13.0 & (12.6 to 13.5$)$ & - \\
\hline & No & 137 & 12.7 & (12.0 to 13.4$)$ & 0.39 \\
\hline \multirow{2}{*}{$\begin{array}{c}\text { Preference for } \\
\text { strong-tasting meals }\end{array}$} & Yes & 215 & 13.3 & (12.8 to 13.8$)$ & - \\
\hline & No & 277 & 12.7 & (12.2 to 13.1$)$ & 0.09 \\
\hline \multirow{2}{*}{$\begin{array}{l}\text { Frequency of using } \\
\text { delicatessen food }\end{array}$} & $\geq 2$ times/week & 199 & 13.2 & (12.6 to 13.7$)$ & - \\
\hline & $\leq 1$ time/week & 293 & 12.8 & (12.4 to 13.3$)$ & 0.33 \\
\hline \multirow[t]{2}{*}{ Frequency of eating out } & $\geq 2$ times/week & 190 & 13.6 & (13.0 to 14.2 ) & - \\
\hline & $\leq 1$ time/week & 302 & 12.6 & (12.1 to 13.0$)$ & 0.005 \\
\hline \multirow{4}{*}{ Whether trying to reduce salt intake } & Trying actively & 37 & 12.8 & (11.5 to 14.1$)$ & - \\
\hline & Trying a little & 169 & 13.1 & (12.5 to 13.7$)$ & 0.42 \\
\hline & Not trying much & 185 & 12.8 & (12.3 to 13.4$)$ & 0.36 \\
\hline & Not trying at all & 101 & 13.0 & (12.2 to 13.8$)$ & 0.99 \\
\hline \multirow{4}{*}{$\begin{array}{l}\text { Use of dashi flavor, broth, or stock } \\
\text { and the natural taste of food }\end{array}$} & Trying actively & 52 & 12.7 & (11.7 to 13.8$)$ & - \\
\hline & Trying a little & 178 & 12.8 & (12.2 to 13.4$)$ & 0.99 \\
\hline & Not trying much & 164 & 13.2 & (12.6 to 13.8$)$ & 0.99 \\
\hline & Not trying at all & 98 & 12.9 & (12.1 to 13.7 ) & 0.99 \\
\hline \multirow{4}{*}{$\begin{array}{l}\text { Whether trying to have a meal con- } \\
\text { sisting of a staple food, main dish, } \\
\text { and side dishes }\end{array}$} & Trying actively & 61 & 12.3 & (11.3 to 13.3 ) & - \\
\hline & Trying a little & 121 & 13.2 & (12.5 to 13.9 ) & 0.99 \\
\hline & Not trying much & 241 & 13.1 & (12.6 to 13.6$)$ & 0.99 \\
\hline & Not trying at all & 69 & 12.7 & (11.7 to 13.6$)$ & 0.99 \\
\hline \multirow{3}{*}{$\begin{array}{l}\text { Frequency of } \\
\text { alcohol consumption }\end{array}$} & Daily & 145 & 13.5 & (12.9 to 14.2 ) & - \\
\hline & Occasionally & 159 & 12.9 & (12.3 to 13.5 ) & 0.46 \\
\hline & $\leq 1$ serving/2 days & 188 & 12.6 & (12.0 to 13.1 ) & 0.11 \\
\hline
\end{tabular}




\section{Continued}

\begin{tabular}{|c|c|c|c|c|c|}
\hline \multirow[b]{2}{*}{ Questionnaire items } & \multirow[b]{2}{*}{ Answer } & \multicolumn{3}{|c|}{$60-79$ years $(\mathrm{N}=268)$} & \multirow[b]{2}{*}{$p$-value } \\
\hline & & $\begin{array}{c}\text { No. } \\
\text { Participants }\end{array}$ & Mean & $95 \%$ CI & \\
\hline \multirow[t]{4}{*}{ Making oneself gorge on a meal } & Everyday & 55 & 11.5 & (10.6 to 12.3$)$ & - \\
\hline & 5 - 6 times/week & 114 & 11.4 & $(10.8$ to 12.0$)$ & 0.99 \\
\hline & 3 - 4 times/week & 74 & 10.4 & (9.7 to 11.2 ) & 0.43 \\
\hline & $\leq 2$ times/week & 25 & 10.1 & (8.8 to 11.3 ) & 0.43 \\
\hline Having $\geq 2$ different staple foods & $\geq 3$ times/week & 51 & 10.5 & (9.6 to 11.4 ) & - \\
\hline per meal & $\leq 2$ times/week & 217 & 11.2 & (10.7 to 11.6 ) & 0.21 \\
\hline \multirow[t]{2}{*}{ Having a 1-dish meal } & $\geq 3$ times/week & 104 & 10.6 & (10.0 to 11.3$)$ & - \\
\hline & $\leq 2$ times/week & 164 & 11.3 & (10.8 to 11.8$)$ & 0.11 \\
\hline \multirow{4}{*}{$\begin{array}{l}\text { Number of simmered } \\
\text { dishes per day }\end{array}$} & $\geq 4$ servings & 27 & 12.2 & (11.0 to 13.5$)$ & - \\
\hline & 2 - 3 servings & 128 & 11.3 & (10.7 to 11.8$)$ & 0.91 \\
\hline & 1 serving & 77 & 11.1 & (10.4 to 11.8$)$ & 0.71 \\
\hline & $\leq 1$ serving/ 2 days & 36 & 9.2 & (8.1 to 10.2$)$ & 0.002 \\
\hline \multirow[t]{5}{*}{ Number of soups per day } & $\geq 3$ servings & 30 & 10.8 & (9.6 to 12.0$)$ & - \\
\hline & 2 servings & 84 & 11.2 & (10.5 to 11.9$)$ & 0.99 \\
\hline & 1 serving & 124 & 11.0 & (10.4 to 11.5$)$ & 0.99 \\
\hline & $\leq 1$ serving/ 2 days & 30 & 11.0 & (9.8 to 12.2 ) & 0.99 \\
\hline & $\geq 2$ types & 105 & 11.9 & (11.3 to 12.5$)$ & - \\
\hline \multirow[t]{2}{*}{$\begin{array}{l}\text { Types of pickled } \\
\text { vegetables per day }\end{array}$} & 1 type & 120 & 10.6 & (10.1 to 11.2$)$ & 0.011 \\
\hline & $\leq 1 / 2$ days & 43 & 10.0 & (9.1 to 11.0$)$ & 0.006 \\
\hline \multirow{2}{*}{$\begin{array}{l}\text { Having salt-cured } \\
\text { fish eggs per day }\end{array}$} & $\geq 1$ time & 71 & 11.2 & (10.4 to 11.9$)$ & - \\
\hline & $\leq 1$ serving $/ 2$ days & 197 & 11.0 & (10.5 to 11.4$)$ & 0.65 \\
\hline \multirow[t]{3}{*}{ Having salty snacks per day } & $\geq 2$ times & 30 & 11.2 & (10.0 to 12.3$)$ & - \\
\hline & 1 time & 105 & 11.3 & (10.7 to 12$)$ & 0.99 \\
\hline & $\leq 1 / 2$ days & 133 & 10.8 & (10.2 to 11.3$)$ & 0.99 \\
\hline \multirow{2}{*}{$\begin{array}{l}\text { Quantity of soup consumed } \\
\text { when eating noodles }\end{array}$} & $\geq 1 / 3$ & 198 & 11.1 & (10.6 to 11.5$)$ & - \\
\hline & Very little & 70 & 10.9 & (10.1 to 11.7 ) & 0.66 \\
\hline \multirow{2}{*}{$\begin{array}{l}\text { Addition of seasoning } \\
\text { to cooked dishes }\end{array}$} & Yes & 104 & 11.2 & (10.5 to 11.8$)$ & - \\
\hline & No & 164 & 10.9 & (10.4 to 11.5$)$ & 0.59 \\
\hline \multirow{2}{*}{$\begin{array}{c}\text { Preference for } \\
\text { strong-tasting meals }\end{array}$} & Yes & 85 & 11.7 & (11.0 to 12.4$)$ & - \\
\hline & No & 183 & 10.7 & (10.2 to 11.2$)$ & 0.020 \\
\hline \multirow{2}{*}{$\begin{array}{l}\text { Frequency of using } \\
\text { delicatessen food }\end{array}$} & $\geq 2$ times/week & 52 & 10.0 & (9.2 to 10.9 ) & - \\
\hline & $\leq 1$ time/week & 216 & 11.3 & (10.8 to 11.7$)$ & 0.016 \\
\hline \multirow[t]{2}{*}{ Frequency of eating out } & $\geq 2$ times/week & 35 & 10.3 & (9.1 to 11.4 ) & - \\
\hline & $\leq 1$ time/week & 233 & 11.2 & (10.7 to 11.6 ) & 0.16 \\
\hline
\end{tabular}




\section{Continued}

\begin{tabular}{|c|c|c|c|c|c|}
\hline \multirow{2}{*}{ Whether trying to reduce salt intake } & Trying actively & 53 & 10.2 & (9.4 to 11.1$)$ & - \\
\hline & Trying a little & 139 & 11.2 & (10.7 to 11.7$)$ & 0.26 \\
\hline \multirow{6}{*}{$\begin{array}{l}\text { Use of dashi flavor, broth, or stock } \\
\text { and the natural taste of food }\end{array}$} & Not trying much & 58 & 11.4 & (10.6 to 12.2$)$ & 0.30 \\
\hline & Not trying at all & 18 & 10.9 & (9.4 to 12.4$)$ & 0.99 \\
\hline & Trying actively & 80 & 11.1 & (10.4 to 11.8$)$ & - \\
\hline & Trying a little & 93 & 10.7 & (10.1 to 11.4$)$ & 0.99 \\
\hline & Not trying much & 69 & 11.9 & (11.2 to 12.7$)$ & 0.60 \\
\hline & Not trying at all & 26 & 9.6 & (8.4 to 10.9 ) & 0.28 \\
\hline \multirow{3}{*}{$\begin{array}{l}\text { Whether trying to have a } \\
\text { meal consisting of a staple food, } \\
\text { main dish, and side dishes }\end{array}$} & Trying actively & 81 & 11.4 & (10.7 to 12.1$)$ & - \\
\hline & Trying a little & 97 & 11.0 & (10.3 to 11.6$)$ & 0.99 \\
\hline & Not trying much & 62 & 10.5 & (9.7 to 11.3 ) & 0.54 \\
\hline \multirow{4}{*}{ Frequency of alcohol consumption } & Not trying at all & 28 & 11.3 & $(10.1$ to 12.6$)$ & 0.99 \\
\hline & Daily & 53 & 12.0 & (11.1 to 12.9 ) & - \\
\hline & Occasionally & 57 & 10.7 & (9.9 to 11.6 ) & 0.14 \\
\hline & $\leq 1$ serving/2 days & 158 & 10.8 & (10.3 to 11.3 ) & 0.11 \\
\hline
\end{tabular}

Analyses were conducted by analysis of covariance for age, gender, BMI, and whether taking medicine or not (antihypertensive agents, insulin or oral hypoglycemic agents, or lipid-lowering agents).

\subsection{Dietary Salt Intake and Responses to the Questionnaire by Gender}

Table 4 shows the dietary salt intake and responses to the questionnaire according to gender. In 4 of the 10 items described above, the fewer times the participants of both genders engaged in the following dietary behaviors the lower their salt intake: making oneself gorge on a meal, having a 1-dish meal, types of pickled vegetables per day, and frequency of eating out. Significant correlations between dietary behavior and lower dietary salt intake remained in male participants in 2 of 10 items: number of simmered dishes per day ( $\geq 4$ servings vs. $\leq 1$ serving/2 days: 16.1 and $11.8 \mathrm{~g}, p=0.005$ ) and frequency of alcohol consumption (daily vs. $\leq 1$ serving/2 days: 14.1 and $12.4 \mathrm{~g}, p=0.005$ ). Among female participants significant associations remained in the following 4 of the 10 items: having two or more different staple foods per serving ( $\geq 3$ vs. $\leq 2$ times/week: 12.2 and $11.2 \mathrm{~g}, p=0.011$ ), having salt-cured fish eggs per day ( $\geq 1$ time vs. $\leq 1$ serving/2 days: 12.0 and $11.1 \mathrm{~g}, p=0.023)$, quantity of soup consumed when eating noodles $(\geq 1 / 3$ vs. very little: 11.6 and $10.7 \mathrm{~g}, p=0.038$ ), and preference for strong-tasting meals (yes vs. no: 11.9 and $11.1 \mathrm{~g}, p=0.021$ ). Among female participants there was also a significant difference in dietary salt intake according to whether or not seasoning was added to cooked dishes (11.8 and $11.0 \mathrm{~g}, p=0.014$ ).

\section{Discussion}

Dietary salt reduction is encouraged worldwide as one of the most important international nutrition challenges. However, detailed evidence indicating salt intake quantitatively for each dietary behavior relating to high salt intake is sparse in Japan, even though dietary salt intake by Japanese is among the highest in developed countries. 
Table 4. Dietary salt intake and responses to the questionnaire on dietary habits potentially relevant to salt intake according to gender.

\begin{tabular}{|c|c|c|c|c|c|}
\hline \multirow[b]{2}{*}{ Questionnaire items } & \multirow[b]{2}{*}{ Answer } & \multicolumn{3}{|c|}{ Male $(\mathrm{N}=374)$} & \multirow[b]{2}{*}{$p$-value } \\
\hline & & $\begin{array}{c}\text { No. } \\
\text { Participants }\end{array}$ & Mean & $95 \%$ CI & \\
\hline \multirow[t]{4}{*}{ Making oneself gorge on a meal } & Everyday & 114 & 13.4 & $(12.6$ to 14.2$)$ & - \\
\hline & 5 - 6 times/week & 172 & 13.2 & (12.6 to 13.8$)$ & 0.99 \\
\hline & 3 - 4 times/week & 68 & 13.6 & (12.5 to 14.6$)$ & 0.99 \\
\hline & $\leq 2$ times/week & 20 & 11.3 & (9.3 to 13.2$)$ & 0.33 \\
\hline Having $\geq 2$ different staple foods & $\geq 3$ times/week & 119 & 13.4 & (12.6 to 14.2$)$ & - \\
\hline per meal & $\leq 2$ times/week & 255 & 13.1 & (12.6 to 13.6$)$ & 0.53 \\
\hline \multirow[t]{2}{*}{ Having a 1-dish meal } & $\geq 3$ times/week & 242 & 13.5 & (12.9 to 14$)$ & - \\
\hline & $\leq 2$ times/week & 132 & 12.8 & (12.0 to 13.5$)$ & 0.14 \\
\hline \multirow{4}{*}{ Number of simmered dishes per day } & $\geq 4$ servings & 13 & 16.1 & (13.8 to 18.4 ) & - \\
\hline & $2-3$ servings & 114 & 13.0 & (12.2 to 13.8$)$ & 0.07 \\
\hline & 1 serving & 182 & 13.6 & (13.0 to 14.2$)$ & 0.25 \\
\hline & $\leq 1$ serving/2 days & 65 & 11.8 & (10.8 to 12.9$)$ & 0.005 \\
\hline \multirow[t]{5}{*}{ Number of soups per day } & $\geq 3$ servings & 39 & 13.4 & (12.1 to 14.7 ) & - \\
\hline & 2 servings & 121 & 13.4 & $(12.7$ to 14.2$)$ & 0.99 \\
\hline & 1 serving & 170 & 13.2 & (12.6 to 13.9$)$ & 0.99 \\
\hline & $\leq 1$ serving/2 days & 44 & 12.3 & (11.0 to 13.5$)$ & 0.99 \\
\hline & $\geq 2$ types & 73 & 13.7 & (12.7 to 14.7$)$ & - \\
\hline \multirow{2}{*}{$\begin{array}{l}\text { Types of pickled } \\
\text { vegetables per day }\end{array}$} & 1 type & 159 & 13.3 & (12.7 to 14$)$ & 0.99 \\
\hline & $\leq 1 / 2$ days & 142 & 12.9 & (12.1 to 13.6$)$ & 0.62 \\
\hline Having salt-cured & $\geq 1$ time & 97 & 13.6 & (12.8 to 14.5$)$ & - \\
\hline fish eggs per day & $\leq 1$ serving/ 2 days & 277 & 13.1 & (12.6 to 13.6$)$ & 0.25 \\
\hline \multirow[t]{3}{*}{ Having salty snacks per day } & $\geq 2$ times & 12 & 12.9 & (10.5 to 15.3$)$ & - \\
\hline & 1 time & 150 & 12.9 & (12.2 to 13.6$)$ & 0.99 \\
\hline & $\leq 1 / 2$ days & 212 & 13.5 & (12.9 to 14.0$)$ & 0.99 \\
\hline \multirow{2}{*}{$\begin{array}{l}\text { Quantity of soup consumed when } \\
\text { eating noodles }\end{array}$} & $\geq 1 / 3$ & 352 & 13.3 & (12.9 to 13.7$)$ & - \\
\hline & very little & 22 & 11.7 & (9.9 to 13.5 ) & 0.09 \\
\hline \multirow{2}{*}{$\begin{array}{l}\text { Addition of seasoning } \\
\text { to cooked dishes }\end{array}$} & Yes & 266 & 13.3 & (12.7 to 13.8$)$ & - \\
\hline & No & 108 & 13.1 & (12.3 to 13.9 ) & 0.78 \\
\hline \multirow{2}{*}{$\begin{array}{l}\text { Preference for } \\
\text { strong-tasting meals }\end{array}$} & Yes & 181 & 13.5 & (12.9 to 14.1$)$ & - \\
\hline & No & 193 & 12.9 & (12.3 to 13.5$)$ & 0.17 \\
\hline \multirow{2}{*}{$\begin{array}{l}\text { Frequency of using } \\
\text { delicatessen food }\end{array}$} & $\geq 2$ times/week & 146 & 13.0 & (12.4 to 13.7$)$ & - \\
\hline & $\leq 1$ time/week & 228 & 13.3 & (12.8 to 13.9 ) & 0.55 \\
\hline \multirow[t]{2}{*}{ Frequency of eating out } & $\geq 2$ times/week & 145 & 13.7 & (13.0 to 14.4 ) & - \\
\hline & $\leq 1$ time/week & 229 & 12.9 & (12.3 to 13.4$)$ & 0.06 \\
\hline
\end{tabular}




\begin{tabular}{|c|c|c|c|c|c|}
\hline Whether trying to & Trying actively & 32 & 13.1 & $(11.5$ to 14.6$)$ & - \\
\hline reduce salt intake & Trying a little & 129 & 13.6 & (12.9 to 14.4$)$ & 0.99 \\
\hline \multirow{6}{*}{$\begin{array}{l}\text { Use of dashi flavor, broth, } \\
\text { or stock and the natural taste of food }\end{array}$} & Not trying much & 134 & 12.9 & $(12.1$ to 13.6$)$ & 0.99 \\
\hline & Not trying at all & 79 & 13.2 & $(12.2$ to 14.1$)$ & 0.99 \\
\hline & Trying actively & 53 & 13.6 & $(12.4$ to 14.7$)$ & - \\
\hline & Trying a little & 122 & 13.0 & (12.2 to 13.8$)$ & 0.99 \\
\hline & Not trying much & 116 & 13.7 & $(12.9$ to 14.5$)$ & 0.99 \\
\hline & Not trying at all & 83 & 12.6 & (11.7 to 13.5$)$ & 0.99 \\
\hline \multirow{3}{*}{$\begin{array}{l}\text { Whether trying to have a } \\
\text { meal consisting of a staple food, } \\
\text { main dish, and side dishes }\end{array}$} & Trying actively & 48 & 12.6 & (11.3 to 13.8$)$ & - \\
\hline & Trying a little & 101 & 13.7 & $(12.9$ to 14.5$)$ & 0.78 \\
\hline & Not trying much & 163 & 13.3 & $(12.6$ to 13.9$)$ & 0.99 \\
\hline \multirow{4}{*}{ Frequency of alcohol consumption } & Not trying at all & 62 & 12.8 & (11.7 to 13.8$)$ & 0.99 \\
\hline & Daily & 148 & 14.1 & (13.4 to 14.7$)$ & - \\
\hline & Occasionally & 112 & 12.9 & $(12.1$ to 13.7$)$ & 0.09 \\
\hline & $\leq 1$ serving $/ 2$ days & 114 & 12.4 & (11.6 to 13.2$)$ & 0.005 \\
\hline \multicolumn{6}{|c|}{ Female $(\mathrm{N}=386)$} \\
\hline Questionnaire items & Answer & $\begin{array}{c}\text { No. } \\
\text { Participants }\end{array}$ & Mean & $95 \%$ CI & $p$-value \\
\hline \multirow[t]{4}{*}{ Making oneself gorge on a meal } & Everyday & 112 & 11.7 & (11.1 to 12.3$)$ & - \\
\hline & 5 - 6 times/week & 182 & 11.5 & (11.0 to 11.9$)$ & 0.99 \\
\hline & 3 - 4 times/week & 75 & 10.9 & (10.1 to 11.6$)$ & 0.51 \\
\hline & $\leq 2$ times/week & 17 & 10.4 & (8.9 to 12.0$)$ & 0.78 \\
\hline Having $\geq 2$ different staple foods & $\geq 3$ times/week & 79 & 12.2 & (11.5 to 12.9$)$ & - \\
\hline per meal & $\leq 2$ times/week & 307 & 11.2 & (10.8 to 11.5$)$ & 0.011 \\
\hline \multirow[t]{2}{*}{ Having a 1-dish meal } & $\geq 3$ times/week & 177 & 11.6 & (11.1 to 12.1$)$ & - \\
\hline & $\leq 2$ times/week & 209 & 11.2 & $(10.7$ to 11.6$)$ & 0.18 \\
\hline \multirow{4}{*}{ Number of simmered dishes per day } & $\geq 4$ servings & 32 & 12.1 & (11 to 13.3$)$ & - \\
\hline & 2 - 3 servings & 156 & 11.6 & (11.1 to 12.1$)$ & 0.99 \\
\hline & 1 serving & 143 & 11.1 & $(10.6$ to 11.7$)$ & 0.69 \\
\hline & $\leq 1$ serving/2 days & 55 & 11.0 & (10.1 to 11.8$)$ & 0.71 \\
\hline \multirow[t]{5}{*}{ Number of soups per day } & $\geq 3$ servings & 27 & 11.8 & (10.6 to 13$)$ & - \\
\hline & 2 servings & 126 & 11.4 & $(10.8$ to 11.9$)$ & 0.99 \\
\hline & 1 serving & 190 & 11.3 & (10.9 to 11.8$)$ & 0.99 \\
\hline & $\leq 1$ serving/2 days & 43 & 11.2 & (10.2 to 12.2$)$ & 0.99 \\
\hline & $\geq 2$ types & 96 & 12.0 & (11.3 to 12.7$)$ & - \\
\hline \multirow[t]{2}{*}{ Types of pickled vegetables per day } & 1 type & 181 & 11.3 & (10.8 to 11.8$)$ & 0.26 \\
\hline & $\leq 1 / 2$ days & 109 & 10.9 & (10.3 to 11.6$)$ & 0.09 \\
\hline
\end{tabular}




\section{Continued}

\begin{tabular}{|c|c|c|c|c|c|}
\hline \multirow{2}{*}{ Having salt-cured fish eggs per day } & $\geq 1$ time & 105 & 12.0 & (11.4 to 12.6$)$ & - \\
\hline & $\leq 1$ serving/2 days & 281 & 11.1 & $(10.8$ to 11.5$)$ & 0.023 \\
\hline \multirow[t]{3}{*}{ Having salty snacks per day } & $\geq 2$ times & 29 & 11.6 & (10.4 to 12.8$)$ & - \\
\hline & 1 time & 187 & 11.6 & (11.1 to 12.1$)$ & 0.99 \\
\hline & $\leq 1 / 2$ days & 170 & 11.1 & (10.6 to 11.6$)$ & 0.99 \\
\hline \multirow{2}{*}{$\begin{array}{l}\text { Quantity of soup consumed } \\
\text { when eating noodles }\end{array}$} & $\geq 1 / 3$ & 301 & 11.6 & (11.2 to 11.9$)$ & - \\
\hline & Very little & 85 & 10.7 & (10 to 11.4 ) & 0.038 \\
\hline \multirow{2}{*}{$\begin{array}{l}\text { Addition of seasoning } \\
\text { to cooked dishes }\end{array}$} & Yes & 193 & 11.8 & (11.3 to 12.3$)$ & - \\
\hline & No & 193 & 11.0 & (10.5 to 11.4$)$ & 0.014 \\
\hline \multirow{2}{*}{ Preference for strong-tasting meals } & Yes & 119 & 11.9 & (11.4 to 12.5$)$ & - \\
\hline & No & 267 & 11.1 & $(10.7$ to 11.5$)$ & 0.021 \\
\hline \multirow{2}{*}{ Frequency of using delicatessen food } & $\geq 2$ times/week & 105 & 11.6 & (11.0 to 12.2$)$ & \\
\hline & $\leq 1$ time/week & 281 & 11.3 & (10.9 to 11.7$)$ & 0.424 \\
\hline \multirow[t]{2}{*}{ Frequency of eating out } & $\geq 2$ times/week & 80 & 11.7 & (11.0 to 12.5$)$ & - \\
\hline & $\leq 1$ time/week & 306 & 11.3 & $(10.9$ to 11.6$)$ & 0.29 \\
\hline \multirow{3}{*}{ Whether trying to reduce salt intake } & Trying actively & 58 & 10.5 & (9.6 to 11.3 ) & - \\
\hline & Trying a little & 179 & 11.3 & (10.9 to 11.8$)$ & 0.44 \\
\hline & Not trying much & 109 & 11.9 & (11.2 to 12.5$)$ & 0.05 \\
\hline \multirow{5}{*}{$\begin{array}{l}\text { Use of dashi flavor, broth, } \\
\text { or stock and the natural taste of food }\end{array}$} & Not trying at all & 40 & 11.6 & (10.5 to 12.6$)$ & 0.63 \\
\hline & Trying actively & 79 & 10.8 & (10.0 to 11.5$)$ & - \\
\hline & Trying a little & 149 & 11.3 & (10.8 to 11.8$)$ & 0.99 \\
\hline & Not trying much & 117 & 11.9 & (11.3 to 12.5$)$ & 0.11 \\
\hline & Not trying at all & 41 & 11.2 & $(10.3$ to 12.2$)$ & 0.99 \\
\hline \multirow{3}{*}{$\begin{array}{l}\text { Whether trying to have a } \\
\text { meal consisting of a staple food, } \\
\text { main dish, and side dishes }\end{array}$} & Trying actively & 94 & 11.4 & $(10.7$ to 12.1$)$ & - \\
\hline & Trying a little & 117 & 11.2 & (10.6 to 11.8$)$ & 0.99 \\
\hline & Not trying much & 140 & 11.4 & (10.9 to 12.0$)$ & 0.99 \\
\hline \multirow{4}{*}{ Frequency of alcohol consumption } & Not trying at all & 35 & 11.5 & $(10.5$ to 12.6$)$ & 0.99 \\
\hline & Daily & 50 & 12.2 & (11.3 to 13.2$)$ & - \\
\hline & Occasionally & 104 & 11.3 & (10.7 to 11.9$)$ & 0.28 \\
\hline & $\leq 1$ serving/2 days & 232 & 11.2 & (10.8 to 11.6 ) & 0.14 \\
\hline
\end{tabular}

Analyses were conducted by analysis of covariance for age, BMI, and whether taking medicine or not (antihypertensive agents, insulin or oral hypoglycemic agents, or lipid-lowering agents).

With the cooperation of Niigata prefecture, the current study revealed that 10 dietary habits were associated with dietary salt intake. These 10 items were within a questionnaire for identification of high salt intake by assessing dietary behavior to improve strategies for salt reduction based on evidence.

The 10 items indicating dietary behavior associated with dietary salt intake are as follows: making oneself gorge on a meal, having 2 or more different staple foods per meal, having a 1-dish meal, number of simmered dishes per day, types of pickled vege- 
tables per day, having salt-cured fish eggs per day, quantity of soup consumed when eating noodles, preference for strong-tasting meals, frequency of eating out, and frequency of alcohol consumption. These items were based on an empirical perspective from interviews with registered dietitians having broad experience in health and nutrition policies. Thus, it can be said that the results of our study support current salt restriction policies.

On the other hand, several items on the questionnaire showed no significant correlation between dietary salt intake and dietary habits. For example, there were no significant differences in dietary salt intake according to the number of times soup was consumed per day. Soup, especially miso (fermented soybean paste) soup, was originally an essential part of one's meals in Japan and is a basic form of traditional Japanese cuisine [13] [14]. Dietary salt restriction policies for the past dozen years or so in Japan have focused on the reduction of the frequency of soup intake as one of the most important targets [8]. The number of times soup is consumed per day was consequently reduced, and our results surveyed in 2014 also showed that more than half of the participants had soup only once or less per day (Table 2). Based on the current study, further action is needed not only to reduce the frequency of soup intake but also to assess the actual salt content in soup and to provide education to reduce the salt concentration in soups.

Additionally, dietary attitudes were not associated with dietary salt intake, such as whether trying to reduce salt intake; use of dashi flavor, broth, or stock and the natural taste of food; and whether trying to have a meal consisting of a staple food, main dish, and side dishes. This finding reflects that knowledge and motivation for reducing salt intake are not effectively connected with concrete actions for salt reduction. It can be said that on the basis of our results, identification of regions and/or individuals with dietary behaviors related to high salt intake and appropriate education within those regions and of individuals is needed for further effective implementation of salt restriction policies.

When participants were divided into groups comprised of 20 to 59 year olds and 60 to 79 year olds, several items had different correlations with dietary salt intake according to the age group. High dietary salt intake was significantly related to the high frequency of having $\geq 2$ different staple foods per meal, having a 1-dish meal, having salt-cured fish eggs, quantity of soup consumed when eating noodles, and frequency of eating out only in participants aged from 20 to 59 years, and in participants aged 60 to 79 years only, high frequency of simmered dishes, consuming many types of pickled vegetables per day and preferring strong-tasting meals were correlated with high dietary salt intake.

The difference in results according to the age group may be closely related to changes in Japanese dietary behavior and culture over the past several years. With economic growth after World War II and the inflow of Western style food, the Japanese dietary intake was improved from weighted toward a carbohydrate diet to well-balanced diet (proportions of fat and carbohydrate as percentages of energy intake: 6.9 and $80.7 \%$ in 1949 [15], and 25.3 and 59.2\% in 1990 [6], respectively). At the same time, the intake of pickled vegetables among typical traditional Japanese salt cured products as one of the major side dishes was reduced from $47.4 \mathrm{~g} /$ day in 1949 [15] to $9.4 \mathrm{~g} /$ day in 2013 [7], 
and 20- to 59-year-old Japanese consume less than half the pickled vegetables consumed by those 60 to 79 years of age ( 7.1 and $14.7 \mathrm{~g} /$ day) [7]. Conversely, as for processed seafood products, the intake amount was increased from $9.8 \mathrm{~g} /$ day to $28.8 \mathrm{~g} /$ day over 64 years [7] [15], due to improvement of processing techniques for seafood [16]. These changes in dietary patterns in Japan may affect the strength of correlations between dietary salt intake and consumption of salt-cured fish eggs and pickled vegetables according to the age group.

In addition, traditional Japanese cuisine like "ichiju san-sai (staple food, 1 main-dish, 2 side-dishes, and 1 soup)" has diminished with the times [13], and the tendency has been toward the spreading fast food industry [8] [17], observed by the increase in frequency of eating out, and the lack of cooking skills and nutrition knowledge by young adults [18] [19]. According to the annual report 2013 from the cabinet office, the percentage of Japanese having the staple food, main dish and side dish assortment almost every day is the lowest in their 20s (men: 25.7\%, women: 51.0\%), and the highest in their $70 \mathrm{~s}$ (men: 77.6\%, women: $81.2 \%$ ), and the prevalence of Japanese 20 - to 59 -year-olds eating out at least three times a week is over twice as much as that of 60 -year-olds and above $(9.5 \%$ vs. $3.3 \%$ ) [18]. Therefore, it can be speculated that only participants aged from 20 to 59 years had a relationship between high dietary salt intake and having a 1-dish meal, including noodles because 1-dish meals are easy to cook and are provided by fast food industries, and the correlation between high dietary salt intake and high frequency of simmered dishes was shown only in participants aged from 60 to 79 years. The insufficient nutrition knowledge in young people may also be related to the high frequency of having $\geq 2$ different staple foods per meal, and tendency of inappropriate self-related dietary behaviors; however, preference for strong-tasting meals is not related.

As mentioned above, creating salt restriction education that is responsive to the characteristics of each generation is needed for acceptance by any generation. Furthermore, to meet the needs of the prevailing food-service and food manufacturing industries in modern society, it is necessary to establish government-led strategies to lessen the amount of salt in the environment, such as the Consensus Action on Salt \& Health in the United Kingdom [20], which has been working to reach a consensus with the food industry and Government for reducing the amount of salt in processed foods [21].

The different correlations between dietary salt intake and items indicating dietary habits were also observed when participants were divided according to gender. As a notably characteristic point, only in women was a significant correlation observed between 2 items relevant to dietary behavior and dietary salt intake: preference for a strong-tasting meal (11.9 and $11.1 \mathrm{~g}, p=0.021)$ and whether adding seasoning to cooked dishes (11.8 and $11.0 \mathrm{~g}, p=0.014$ ). As the reason for the gender difference, it may be that men have less knowledge about foods and eating patterns for a healthy life compared with women and women tend to have higher general cooking skills than men [19] [22]. Moreover, the prevalence of men who cook every day is lower than women [7]. Married men particularly habitually have meals cooked by their wives, thus they tend to be passive about acquiring knowledge and practical experience regarding food. Understanding the actual status of dietary habits and comprehension of dietary salt reduction based on gender is required for performing and developing an educational 
program for salt reduction.

The present study had several limitations. First, the participants were all residents of Niigata prefecture. It is reported that many countries have regional differences in dietary habits and nutritional intake [7] [23] [24] [25] including salt intake in Japan [26]. Additional research in other prefectures is of importance for nationwide salt reduction policies. Second, this study included only participants aged 20 years or older. A proper lifestyle, which includes proper dietary habits, is the basis for healthy status in childhood and tends to persist throughout life [27] [28]. Further studies involving minors are required in the future. Another limitation is that estimated dietary salt intake was obtained from SMU [29]. However, estimated sodium excretion from SMU was validated with that of 24-h urinary excretion with highly significant correlations $(\mathrm{r}=0.728$, $p<0.001$ ) [12] and has reported use in a number of epidemiological studies [30] [31].

\section{Conclusion}

In conclusion, we clarified 10 items related to dietary behavior that were associated with dietary salt intake in cooperation with Niigata prefecture, Japan. These items may be used for developing an evidenced-based questionnaire that would indicate specific dietary behaviors that could achieve a reduction in salt intake and that could assess salt intake regionally and/or in individuals. Based on our current findings, identification of and education in regions and/or individuals with dietary habits related to high salt intake, and further discussion and cooperation among public health nutritionists and other professionals in the government as well as university researchers are needed for practicing the Plan-Do-Check-Act cycle, which has a scientific basis, and development of an effective program for dietary salt reduction.

\section{Acknowledgements}

Study concept and design: Chika Horikawa, Nobuko Murayama.

Creation of questionnaire: EriTochikura, Emi Ishida, Miyo Kojima, SumieIsobe, Kazue Suzuki, Kyoko Fueta, Miyoko Kira, MizueSasaya, Misato Koide, AsakoOyanagi, Rika Yonekura.

Acquisition of data: Kyoko Fueta, Miyoko Kira, YaeIriyama, Yumi Nakajima.

Analysis of data: Chika Horikawa, Nobuko Murayama.

Interpretation of data: Chika Horikawa, Nobuko Murayama, EriTochikura, Emi Ishida, Miyo Kojima, SumieIsobe, Kazue Suzuki, Kyoko Fueta, Miyoko Kira, MizueSasaya, Misato Koide, AsakoOyanagi, Rika Yonekura, ChihoHatano, Junichi Horii.

Drafting of the manuscript: Chika Horikawa, Nobuko Murayama.

Critical revision of the manuscript for important intellectual content: ChihoHatano, Junichi Horii.

Dr. Horikawa is a recipient of a Grant-in-Aid for Scientific Research (15K16232) from the Japan Society for the Promotion of Science (JSPS). The research organizations providing funding support did not have any role in the design or conduct of the study; in the correction, management, analysis, and interpretation of the data; or in the preparation, review, or approval of the manuscript. Dr. Horikawa had full access to all of the data in the study and takes responsibility for the integrity of the data and accuracy of 
the data analysis. The authors declare that there is no conflict of interest associated with this manuscript.

\section{References}

[1] World Health Organization (2007) Reducing Salt Intake in Populations-Report of a WHO Forum and Technical Meeting. WHO Document Production Services, Geneva.

[2] World Health Organization (2013) Global Action Plan for the Prevention and Control of NCDs 2013-2020. WHO Document Production Services, Geneva.

[3] He, F.J. and MacGregor, G.A. (2009) A Comprehensive Review on Salt and Health and Current Experience of Worldwide Salt Reduction Programmes. Journal of Human Hypertension, 23, 363-384. https://doi.org/10.1038/jhh.2008.144

[4] Ministry of Health, Labour and Welfare, Japan (2015) Overview of Dietary Reference Intakes for Japanese (2015).

http://www.mhlw.go.jp/file/06-Seisakujouhou-10900000-Kenkoukyoku/Overview.pdf

[5] Ministry of Health and Welfare, Japan (1983) The National Nutrition Survey in Japan, 1981. Ministry of Health and Welfare, Tokyo.

[6] National Institute of Health and Nutrition, Japan (2004) Outline of the National Health and Nutrition Survey Japan. http://www0.nih.go.jp/eiken/english/research/pdf/nhns2004.pdf

[7] Ministry of Health, Labor and Welfare, Japan (2013) The National Health and Nutrition Survey in Japan. http://www.mhlw.go.jp/bunya/kenkou/eiyou/dl/h25-houkoku.pdf

[8] Murayama, N. (2015) Advocacy Activities at the Local Government Level: Establishing Sodium Restriction Policies through Data Analysis and Plan-Do-Check-Act in Cooperation with Local Government. Japanese Journal of Health Education and Promotion, 23, 231-236.

[9] Charlton, K.E., Steyn, K., Levitt, N.S., Jonathan, D., Zulu, J.V. and Nel, J.H. (2008) Development and Validation of a Short Questionnaire to Assess Sodium Intake. Public Health Nutrition, 11, 83-94. https://doi.org/10.1017/S1368980007000146

[10] Claro, R.M., Linders, H., Ricardo, C.Z., Legetic, B. and Campbell, N.R. (2012) Consumer Attitudes, Knowledge, and Behavior Related To Salt Consumption in Sentinel Countries of the Americas. Revista Panamericana de Salud Pública, 32, 265-273. https://doi.org/10.1590/S1020-49892012001000004

[11] Lee, J.Y., Cho, D.S. and Kim, H.J. (2012) The Effect of Salt Usage Behavior on Sodium Intake and Excretion among Korean Women. Nutrition Research and Practice, 6, 232-237. https://doi.org/10.4162/nrp.2012.6.3.232

[12] Kawasaki, T., Itoh, K., Uezono, K. and Sasaki, H. (1993) A Simple Method for Estimating $24 \mathrm{~h}$ Urinary Sodium and Potassium Excretion from Second Morning Voiding Urine Specimen in Adults. Clinical and Experimental Pharmacology and Physiology, 20, 7-14. https://doi.org/10.1111/j.1440-1681.1993.tb01496.x

[13] Kumakura, I. (2014) Washoku Joins UNESCO's Intangible Cultural Heritage List. Food Culture, 24, 3-5.

[14] Goto, K., Ominami, C., Song, C., Murayama, N. and Wolff, C. (2014) Globalization, Localization and Food Culture: Perceived Roles of Social and Cultural Capitals in Healthy Child Feeding Practices in Japan. Global Health Promotion, 21, 50-58. https://doi.org/10.1177/1757975913511133

[15] Ministry of Health and Welfare (1951) The National Nutrition Survey in Japan, 1951. Ministry of Health and Welfare, Tokyo.

[16] Ministry of Health and Welfare (1958) The National Nutrition Survey in Japan, 1958. Ministry of Health and Welfare, Tokyo.

[17] Watsons, J.L. (1997) Golden Arches East: McDonald's in East Asia. Stanford University 
Press, Stanford.

[18] Cabinet Office (2013) Shokuiku Promotion Policies: FY2012 (White Paper on Shokuiku). Shobi Printing Co., Government of Japan, Tokyo.

[19] Kishida, E., Masuzawa, Y., Shibuya, K., Kubo, K., Horikoshi, M., Nakanishi, Y., Naruse, A. and Hosotani, K. (2002) Questionnaire for Food and Nutrition Education Program Taking Account of the Learners' Viewpoint-Leaming of Basic Cooking Focused on Younger Generation and Middle-Aged Men. Journal of Home Economics of Japan, 53, 79-88.

[20] University of London (1999) Consensus Action on Salt and Health. http://www.actiononsalt.org.uk/index.html

[21] He, F.J., Pombo-Rodrigues, S. and MacGregor, G.A. (2014) Salt Reduction in England from 2003 to 2011: Its Relationship to Blood Pressure, Stroke and Ischaemic Heart Disease Mortality. BMJ Open, 4, e004549. https://doi.org/10.1136/bmjopen-2013-004549

[22] Omori, K. (2003) Relationships between Knowledge, Cooking Technique, Self-Efficacy and Behavior for Healthy Eating among Japanese Senior High School Students. Journal of Home Economics of Japan, 54, 993-1005.

[23] Hajjar, I. and Kotchen, T. (2003) Regional Variations of Blood Pressure in the United States Are Associated with Regional Variations in Dietary Intakes: The NHANES-III Data. Journal of nutrition, 133, 211-214.

[24] Perrin, A.E., Dallongeville, J., Ducimetière, P., Ruidavets, J.B., Schlienger, J.L., Arveiler, D. and Simon, C. (2005) Interactions between Traditional Regional Determinants and SocioEconomic Status on Dietary Patterns in a Sample of French Men. British Journal of Nutrition, 93, 109-114. https://doi.org/10.1079/BJN20041280

[25] Jelinić, J.D., Pucarin-Cvetković, J., Nola, I.A., Senta, A., Milosević, M., and Kern, J. (2009) Regional Differences in Dietary Habits of Adult Croatian Population. Collegium Antropologicum, 33, 31-34.

[26] Tomonari, T., Fukuda, M., Miura, T., Mizuno, M., Wakamatsu, T.Y., Ichikawa, T., Miyagi, S., Shirasawa, Y., Ito, A., Yoshida, A., Omori, T. and Kimura, G. (2011) Is Salt Intake an Independent Risk Factor of Stroke Mortality? Demographic Analysis by Regions in Japan. Journal of the American Society of Hypertension, 5, 456-462. https://doi.org/10.1016/j.jash.2011.07.004

[27] Mikkila, V., Rasanen, L., Raitakari, T., Pietinen, P. and Viikari, J. (2005) Consistent Dietary Patterns Identified from Childhood to Adulthood: The Cardiovascular Risk in Young Finns Study. British Journal of Nutrition, 93, 923-931. https://doi.org/10.1079/BJN20051418

[28] McGowan, L., Cooke, L.J., Gardner, B., Beeken, R.J., Croker, H. and Wardle, J. (2013) Healthy Feeding Habits: Efficacy Results from a Cluster-Randomized, Controlled Exploratory Trial of a Novel, Habit-Based Intervention with Parents. American Journal of Clinical Nutrition, 98, 769-777. https://doi.org/10.3945/ajcn.112.052159

[29] McLean, R.M. (2014) Measuring Population sodium Intake: A Review of Methods. Nutrients, 6, 4651-4662. https://doi.org/10.3390/nu6114651

[30] O’Donnell, M.J., Yusuf, S., Mente, A., Gao, P., Mann, J.F., Teo, K., McQueen, M., Sleight, P., Sharma, A.M., Dans, A., Probstfield, J. and Schmieder, R.E. (2011) Urinary Sodium and Potassium Excretion and Risk of Cardiovascular Events. JAMA, 306, 2229-2238. https://doi.org/10.1001/jama.2011.1729

[31] Mente, A., O’Donnell, M.J., Rangarajan, S., McQueen, M.J., Poirier, P., Wielgosz, A., Morrison, H., Li, W., Wang, X., Di, C., Mony, P., Devanath, A., Rosengren, A., Oguz, A., Zatonska, K., Yusufali, A.H., Lopez-Jaramillo, P., Avezum, A., Ismail, N., Lanas, F., Puoane, T., Diaz, R., Kelishadi, R., Iqbal, R., Yusuf, R., Chifamba, J., Khatib, R., Teo, K., Yusuf, S. and PURE Investigators (2014) Association of Urinary Sodium and Potassium Excretion with Blood Pressure. New England Journal of Medicine, 371, 601-611.

https://doi.org/10.1056/NEJMoa1311989 
Submit or recommend next manuscript to SCIRP and we will provide best service for you:

Accepting pre-submission inquiries through Email, Facebook, LinkedIn, Twitter, etc. A wide selection of journals (inclusive of 9 subjects, more than 200 journals) Providing 24-hour high-quality service

User-friendly online submission system

Fair and swift peer-review system

Efficient typesetting and proofreading procedure

Display of the result of downloads and visits, as well as the number of cited articles Maximum dissemination of your research work

Submit your manuscript at: http://papersubmission.scirp.org/

Or contact fns@scirp.org 